\title{
Antioxidant and Antimicrobial Activities of $\beta$-Caryophyllene dominated Leaf Essential oil of Trichilia monadelpha (Thonn.) JJ De Wilde
}

\author{
Odeja O.Oluwakayode ${ }^{1}$ and Patricia A. Onocha ${ }^{2 *}$ \\ ${ }^{1}$ Department of Chemistry, College of Science, Federal University of Petroleum Resources, Effurun, Delta State; \\ Nigeria. \\ ${ }^{2}$ Natural Products/Medicinal Chemistry Unit, Department of Chemistry, Faculty of Science, University of \\ Ibadan, Ibadan; Nigeria. *E-mail: triciaonocha@yahoo.com
}

\begin{abstract}
Trichilia monadelpha (Thonn) JJ De Wilde (Meliaceae) is an essential plant of diverse medicinal uses in folk medicine. It is deployed in the treatment of ulcers/epidermal infections, epilepsy, gonorrhea and inflammatory disorders such as arthritis etc. This study investigated the leaf essential oil constituents of T. monadelpha along with the corresponding antioxidant and antimicrobial activities. The essential oil of fresh leaves of T. monadelpha was isolated by hydrodistillation using all glass Clevenger distillation apparatus while the identification and characterization was done by Gas Chromatography-Mass Spectrometry (GC-MS). Antioxidant activity was carried out by scavenging effect on 2,2-diphenyl-1-picrylhydrazyl radical (DPPH) at $517 \mathrm{~nm}$ in a UV-Visible spectrophotometric assay with Ascorbic acid, Butylated hydroxylanisole (BHA) and $\alpha$-Tocopherol as reference standards. Antimicrobial assay was examined by Agar diffusion method. A total of fifteen compounds were identified in the essential oil with $\beta$-Caryophyllene $(35.41 \%)$ as the major constituent. The oil demonstrated moderate inhibition against seven of the ten microorganisms used for the assay, namely: Staphylococcus aureus, Esherichia coli, Bacillus subtilis, Pseudomonas aerugunosa, Candida albicans, Aspergillus niger, Rhizopus stolonifer. The antioxidant activity of the essential oil ( $\mathrm{IC}_{50}$ of $3.72 \mathrm{mg} / \mathrm{ml}$ ) though lower than that of ascorbic acid $\left(\mathrm{IC}_{50}\right.$ of $\left.1.47 \mathrm{mg} / \mathrm{ml}\right)$ and $\mathrm{BHA}\left(\mathrm{IC}_{50}\right.$ of $\left.1.88 \mathrm{mg} / \mathrm{ml}\right)$ was however better than that of $\alpha$-Tocopherol (IC ${ }_{50}$ of 4.83 $\mathrm{mg} / \mathrm{ml}$ ). The results obtained corroborated the uses of Trichilia monadelpha in folk medicine.
\end{abstract}

Keywords: Gas Chromatography-Mass Spectrometry, Essential oil, $\beta$-Caryophyllene, Antioxidant and Antimicrobial Activities.

DOI: $10.7176 / \mathrm{JNSR} / 11-16-05$

Publication date:August $31^{\text {st }} 2020$

\section{Introduction}

Plants have been the major source in the treatment of various diseases, especially in developing countries (Benoit-Vical, 2006). Some of these plant extracts and phytochemicals are known to have antimicrobial properties and are of great significance in therapeutic treatments. A number of studies have been conducted in different countries to demonstrate such efficacy (Senatore et al, 2007; Langseth et al, 1996). Medicinal plant constituents have a long history of use in old and modern medicines. They are the source of important medications such as vincristine, codeine, quinine, morphine, digoxin, atropine and others, some of which are still currently in use (Raskin et al, 2002).

Essential oils from aromatic plants and spices have a long history of use as natural microbial agents in folk medicine. They also have wide applications in food, cosmetics and pharmaceutical industries as these oils are known to possess antimicrobial, antiviral and antioxidant properties. Essential oils are employed as antioxidants due to their small molecular size and their ability to easily penetrate the skin tissue. They are lipid soluble and are capable of penetrating the membranes easily even in conditions where oxygen deficiency leads to hardening of membranes. Studies reveal that essential oils serve as powerful antioxidants that produce adverse environment for damaging free radicals, thus preventing mutations and oxidants in cells. They therefore function as scavengers for free radicals. Essential oils are extracted from different plant parts: fruits, leaves, flowers, barks, roots and seeds with each part possessing unique characteristics (Bako et al, 2005; Bray, 1999; Potterat, 1997).

Oxidative damage in human cells or tissues is mainly due to the uncontrolled production of oxygen from free radicals. These are harmful substances produced in the body during the normal metabolic processes. Bacterial, fungal and viral infections have also been reported to produce reactive oxygen species. Environmental chemicals 
such as pesticides and other chemicals like alcohol, cigarette smoking, burning of organic matter, UV radiations and automobile pollution also contribute to free radical generation (Sato et al, 1995). Medicinal plants with antibacterial and antioxidant potentials are thus used as alternative therapy for bacterial infections and many kind of degenerative diseases in folk medicine (Cai, 1996).

However, the need for new antioxidant and antimicrobial agents has increased remarkably over the years due to multiple drug resistance and fewer side effects of drugs from natural sources as compared to synthetic drugs. T. monadelpha (Thonn) JJ De Wilde (Meliaceae) is a medium-sized tree that grows 12-20 m high, distributed in deciduous and semi-deciduous secondary forests, often in wet places in West Africa. T. monadelpha has diverse application in folklore in the treatment of ailments namely: Yaws, Ulcers, abortion, arthritis, cough, gonorrhea, syphilis, chancres and syphilistic sores, wounds/cuts/epidermal infections, rickets, sterility, amenorrhea, stomach pain, gastrointestinal pain and disorders, dysentery and fever (Burkill, 1997; Abbiw, 1990).

Earlier preliminary phytochemical screening of different stem bark extracts of $T$. monadelpha revealed the presence of Alkaloids, saponins, flavonoids, tannins, glycosides, terpenoids and sterols. Some of the investigated pharmacological activities of T. monadelpha include: antioxidant, wound healing, analgesic, antiinflammatory, and anti-anaphylactic properties (Ben et al.,2013; Woode et al., 2012\& 2013; Tuwari et al.,2011; Kokate, 2005), analgesic (Dos Santos et al., 2010), antidepressant (KwamiEdem et al., 2018), antimicrobial and antioxidant (Quartey, 2014). In a continuing search for more potent natural products with fewer side effects (Odeja et al., 2020; Oloyede et al., 2020; Onocha et al., 2016), we present the result of the investigation of the chemical constituent, antioxidant and antimicrobial activities of the leaf essential oil of T. monadelpha which is being reported for the first time.

\section{Materials and methods}

\subsection{Plant material}

Fresh leaves of T. monadelpha were collected from botanical garden of University of Ibadan, Ibadan. Specimens were identified and authenticated at Forest Research Institute of Nigeria (FRIN), Oyo State, Nigeria where a voucher specimen with herbarium number FHI 112655 was deposited in the FRIN herbarium. The leaves were chopped and hydro-distilled immediately.

\subsection{Chemicals and reagents}

Hexane, methanol, butylated hydroxyamisole (BHA) and 2, 2-diphenyl-1-picrylhydrazyl radical (DPPH), ascorbic acid and $\alpha$-tocopherol were obtained from Sigma Chemical Co. (Germany).

\subsection{Equipment and Apparatus}

UV-Visible Spectrophotometer (Unicol 200 and Perkin Elmer lambda 25 models), GC-Mass spectrophotometer (Agilent Technologies), Hydro distiller-all glass Clavenger apparatus.

\subsection{Isolation of essential oil}

The oil was obtained by hydro-distillation on all glass Clevenger distillation apparatus for $4 \mathrm{hrs}$ in accordance with the British pharmacopoeia specifications (1980). The essential oil (TML) was collected and stored at $4^{\circ} \mathrm{C}$ prior to analysis.

\subsection{Gas Chromatography-Mass Spectrometry}

GC-MS analyses of the essential oil was analyzed on an Aligent Technologies 7890A GC system coupled to a 5975c VLMSD mass spectrometer with an injector 7683b series device. An Agilent (9091)-413:325 ${ }^{\circ} \mathrm{C} \mathrm{HP}-5$ column $(30 \mathrm{~m} \times 320 \mu \mathrm{m} \times 0.25 \mu \mathrm{m})$ was used with helium as carrier gas at flow rate of $3.3245 \mathrm{~mL} \mathrm{~min}^{-1}$. The GC oven temperature was initially programmed at $50^{\circ} \mathrm{C}$ (hold for $1 \mathrm{~min}$ ) and finally at $300^{\circ} \mathrm{C}$ (hold for $5 \mathrm{mins}$ ) at a rate

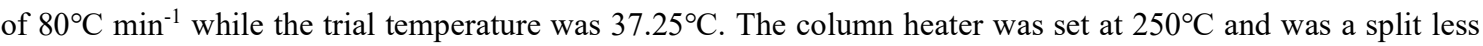
mode while the pressure was 10.153 psi with an average velocity of $66.45 \mathrm{~cm} \mathrm{sec}^{-1}$ and a hold-up time of 0.75245 min was recorded. Mass spectrometry was run in the Electron Impact mode (EI) at $70 \mathrm{eV}$. The percentage compositions were obtained from electronic integration measurements using Flame Ionization Detector (FID) set at $250^{\circ} \mathrm{C}$. The peak numbers and relative percentages of the characterized components are given in Table 1. 


\subsection{Antioxidant Activity}

A $0.5 \mathrm{ml}$ of the radical source of 2, 2-diphenyl-1-picrylhydrazyl radical (DPPH) solution in methanol was prepared and $3 \mathrm{ml}$ of this solution was mixed with $1 \mathrm{ml}$ of the oil sample in methanol (Oloyede et al., 2011; Onocha et al., 2011). The decrease in absorption (A) at $517 \mathrm{~nm}$ of DPPH was measured after $10 \mathrm{mins}$ of incubation. The actual decrease in absorption was measured against that of control and the percentage inhibition (\% I) was also calculated. The same experiment was carried out on ascorbic acid, $\alpha$-Tocopherol and butylated hydroxylanisole (BHA) which are known antioxidants. All test and analysis were run in triplicates and the result obtained were averaged. The activities were determined as a function of their \% inhibition which was calculated using the formula:

$$
\% I=\frac{\text { Acontrol-Asample }}{\text { Acontrol }} \times 100
$$

\subsection{Antimicrobial Activity}

All microorganisms were clinical isolates obtained from the Department of Pharmaceutical Microbiology, University of Ibadan, Nigeria. The leaf essential oil of T. monadelpha was tested against 10 strains of microorganisms consisting of 7 bacteria: 5 Gram negative (Escherichia coli and Klebsiella pneumonia, Salmonella typhi, Klebsiellae pneumonia, Pseudomonas aeruguinosa), 2 Gram-positive: (Staphylococcus aureus and Bacillus subtilis) and 3 fungi (Candida albicans, Penicillum notatum and Aspergillus niger). Agar diffusion method (Pour broth dilutions and surface plate for antibacterial and antifungal activities, respectively) was employed (Kalemba \& Kunicka, 2003; Okpala et al., 2019). Oil sample was prepared such that $1 \mathrm{ml}$ of the oil was regarded as $100 \%$ concentration. $0.5 \mathrm{ml}$ into $0.5 \mathrm{ml}$ of Hexane gave $50 \%$ concentration and $25 \%$ concentration was obtained using serial dilution. Hexane was used as a negative control, Gentamicin $(10 \mu \mathrm{g} / \mathrm{mL})$ as a positive control for bacteria and Tioconazole $(0.7 \mathrm{mg} / \mathrm{mL})$ as positive control for Fungi. All tests were carried out in triplicates. Observed zones of inhibition of growth were measured and recorded in millimetre $(\mathrm{mm})$.

\section{Results and Discussion}

3.1 Identification of components

The individual constituents of the oil were identified on the basis of their retention indices, determined with reference to a homologous series of n-alkanes and by comparison of their mass spectral fragmentation patterns (NIST 08.L database/chemstation data system) with data previously reported in literature by Adams (2001), Joulain \&Konig, (1998) and Mclafferty \&Stauffer (1998). The hydrodistillation of the leaves of T. monadelpha gave a high level of sesquiterpenes hydrocarbon in the essential oil. Fifteen compounds were identified in the essential oil representing a total percentage composition of $89.44 \%$ with $\beta$-Caryophyllene $(35.41 \%)$ as the major compound. Other constituents identified include: 1-Aminomethyl cyclododecanol (15.14\%), Cyclohexadecane (8.22\%), $\alpha$-Cubebene (6.56\%), 1,1,4,8-Tetramethyl-4,7,10-cycloundecatriene (3.04), Isopropyl ester (3.11\%), Cycloeicosane (2.75\%), (Z,Z)-2,6-Farnesol (2.61\%), 1-(1,5-Dimethylhexyl)-4-(4-methylpentyl)cyclohexane $(2.21 \%)$, Squalene $(2.06 \%)$ etc. The volatile metabolites were predominantly sesquiterpenes hydrocarbon in nature $(45.01 \%)$ and contained $2.62 \%$ sesquiterpenoids, while the non-terpene derivatives comprises of $37.79 \%$ as shown in Table 1. $\beta$-Caryophyllene is a bicyclic sesquiterpene reported to be one of the major active components of essential oils derived from a large number of spice and food plants such as: basil (Ocimum spp.), cinnamon (Cinnamomum spp.), black pepper (Piper nigrum L.), cloves (Syzygium aromaticum), cannabis (Cannabis sativa L.), lavender (Lavandula angustifolia), oregano (Origanum vulgare L.) and rosemary (Rosmarinus officinalis) (Fidyt et al., 2016). Its medicinal implication has also been reported. These include: anti-inflammatory (Medeiros et al., 2007), anticarcinogenic (Langhasova et al., 2014), antimicrobial (Sabulal et al., 2006), antioxidative (Singh et al., 2006) and analgesic activities (Klauke et al., 2013). 
Table 1: Chemical composition of the leaf essential oils of Trichilia monadelpha

\begin{tabular}{|l|l|l|l|}
\hline S/N & Retention Index & Compounds & \% Composition \\
\hline 1 & - & 9-(1-Methylethylidene)-bicyclo[6.1.0]nonane & 2.07 \\
\hline 2 & - & $1-(1,5-$ Dimethylhexyl)-4-(4-methylpentyl)cyclohexane & 2.21 \\
\hline 3 & - & Bromoacetic acid & 1.6 \\
\hline 4 & - & Cycloeicosane & 2.75 \\
\hline 5 & - & 1-Aminomethyl cyclododecanol & 15.14 \\
\hline 6 & $\mathbf{1 4 7 6}$ & $\boldsymbol{\beta}$-Caryophyllene & $\mathbf{3 5 . 4 1}$ \\
\hline 7 & 1519 & $\alpha-$ Cubebene & 6.56 \\
\hline 8 & 1519 & 1,1,4,8-Tetramethyl-4,7,10-cycloundecatriene & 3.04 \\
\hline 9 & 1695 & (Z,Z)-2,6-Farnesol & 2.61 \\
\hline 10 & 1883 & Cyclohexadecane & 8.22 \\
\hline 11 & 1921 & 6,10,14-Trimethyl-5,9,13-pentadecatrien-2-one & 1.09 \\
\hline 12 & 2023.5 & Isopropyl ester & 3.11 \\
\hline 13 & 2828 & Squalene & 2.06 \\
\hline 14 & 2835.8 & Spinacene & 1.97 \\
\hline 15 & 3745.68 & Octadecyl ester & 1.6 \\
\hline & & Total & 89.44 \\
\hline
\end{tabular}

\subsection{Antioxidant Activity}

Antioxidant activity (scavenging assay) of essential oil of T. monadelpha leaves was determined with DPPH method. The scavenging assay was carried out to determine the ability of the essential oil in inhibiting free radicals. The leaf essential oil of $T$. monadelpha displayed a moderate free radical scavenging activity at all the concentrations varying from $60.5 \%$ to $53.6 \%$ as shown in Table 2 . The antioxidant activity of the essential oil though lower than that of ascorbic acid and BHA was however better than that of $\alpha$-Tocopherol. Furthermore, the scavenging activity effectiveness was measured through $\mathrm{IC}_{50}$ (the concentration of the samples required to scavenge $50 \%$ of the hydroxyl radicals. The lower the $\mathrm{IC}_{50}$, the greater the overall effectiveness of the suspected antioxidant potency. From the results obtained, the antioxidant effectiveness is as follows: ascorbic acid (1.47 $\mathrm{mg} / \mathrm{ml})>$ butylated hydroxylanisole $(1.88 \mathrm{mg} / \mathrm{ml})>\operatorname{TML}(3.72 \mathrm{mg} / \mathrm{ml})>\alpha$-Tocopherol $(4.83 \mathrm{mg} / \mathrm{ml})$. The percentage inhibition is presented in Table 2 and Fig. 1.

Table 2: DPPH radical scavenging activity of leaf essential oil (TML) and standards

\begin{tabular}{|l|l|l|l|l|}
\hline \multirow{2}{*}{$\begin{array}{c}\text { Concentration } \\
(\mathrm{mg} / \mathrm{ml})\end{array}$} & \multicolumn{4}{|l|}{ Absorbance values from scavenging effects on DPPH at 517nm } \\
\cline { 2 - 5 } & TML & BHA & Ascobic Acid & $\boldsymbol{\alpha}$-Tocopherol \\
\hline $\mathbf{1 . 0}$ & 60.5 & 84.7 & 92.1 & 53.7 \\
\hline $\mathbf{0 . 5}$ & 59.7 & 82.8 & 92.0 & 53.6 \\
\hline $\mathbf{0 . 2 5}$ & 58.3 & 75.2 & 91.2 & 52.2 \\
\hline $\mathbf{0 . 1 2 5}$ & 58.2 & 81.2 & 91.1 & 48.2 \\
\hline $\mathbf{0 . 0 6 2 5}$ & 53.6 & 75.2 & 91.1 & 45.0 \\
\hline $\mathrm{IC}_{50}$ & 3.72 & 1.88 & 1.47 & 4.83 \\
\hline
\end{tabular}




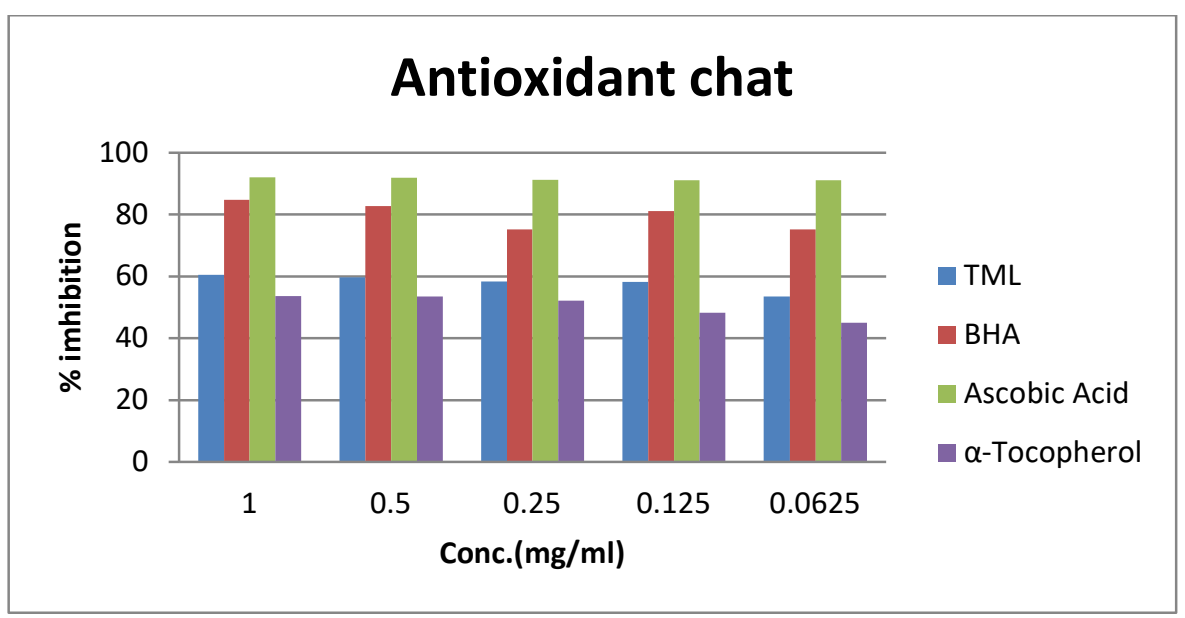

Fig 1: \% Inhibition of leaf essential oil (TML) and standards

\subsection{Antimicrobial Activity}

The antimicrobial activity of the essential oil was determined against ten microorganisms. In vitro antimicrobial activity of the leaf essential oil of $T$. monadelpha resulted in a range of growth inhibition patterns against the studied pathogenic microorganism. The antimicrobial assay showed that at high concentration of $200 \mu \mathrm{g} / \mathrm{mL}, 100$ $\mu \mathrm{g} / \mathrm{mL}$ and $50 \mu \mathrm{g} / \mathrm{mL}$ the essential oil was moderately active against Staphylococcus aureus, Esherichia coli, Bacillus subtilis, Pseudomonas aerugunosa, Candida albicans, Aspergillus niger, Rhizopus stolonifer. At 200 $\mu \mathrm{g} / \mathrm{mL}$, the range was $20 \mathrm{~mm}$ to $16 \mathrm{~mm}$, at $100 \mu \mathrm{g} / \mathrm{mL}$, the range was $18 \mathrm{~mm}$ to $14 \mathrm{~mm}$ while $50 \mu \mathrm{g} / \mathrm{mL}$, the range was $14 \mathrm{~mm}$ to $10 \mathrm{~mm}$ zone of inhibition. However, the extract showed more activity against Pseudomonas aeruguinosa, Bacillus subtilis, Candida albicans, Aspergillus niger. At lower concentration of $25 \mu \mathrm{g} / \mathrm{mL}$, the zone of inhibition was between $12 \mathrm{~mm}$ to $10 \mathrm{~mm}$ for Staphylococcus aureus, Esherichia coli, Bacillus subtilis, Pseudomonas aerugunosa, Candida albicans, Aspergillus niger. At $12.5 \mu \mathrm{g} / \mathrm{mL}$, the extract showed activity only against Pseudomonas aeruguinosa, the zone of inhibition was $10 \mathrm{~mm}$. At $6.25 \mu \mathrm{g} / \mathrm{mL}$ the extract showed no inhibition against all the tested micro-organisms. The diameter of zone of inhibition is presented in Table 3 .

Table 3: Antimicrobial analysis of the leaf essential oils of Trichilia monadelpha (TML)

\begin{tabular}{|l|l|l|l|l|l|l|l|l|l|l|}
\hline \multirow{2}{*}{ Concentration $(\mu \mathbf{g} / \mathbf{m L})$} & \multicolumn{9}{|l|}{ Diameter of zone of inhibition of microorganisms $(\mathbf{m m})$} \\
\cline { 2 - 12 } & S.A & E.C & B.S & P.A & S.T & KP & C.A & A.N & RS & PN \\
\hline 200 & 16 & 16 & 18 & 20 & - & - & 18 & 18 & 16 & - \\
\hline 100 & 14 & 14 & 14 & 18 & - & - & 14 & 14 & 14 & - \\
\hline 50 & 12 & 12 & 12 & 14 & - & - & 12 & 12 & 10 & - \\
\hline 25 & 10 & 10 & 10 & 12 & - & - & 10 & 10 & - & - \\
\hline 12.5 & - & - & - & 10 & - & - & - & - & - & - \\
\hline 6.25 & - & - & - & - & - & - & - & - & - & - \\
\hline$-\mathrm{ve}$ & - & - & - & - & - & - & - & - & - & - \\
\hline$+\mathrm{ve}$ & 40 & 38 & 40 & 38 & 40 & 38 & 28 & 28 & 28 & 26 \\
\hline
\end{tabular}

SA: Staphylococcus aureus, EC: Eshericha coli, B.S: Bacillus subtilis, PA: Pseudomonas aeruguinosa, ST: Salmonella typhi, KP: Klebsiellae Pneumonia, CA: Candida albicans, AN: Aspergillus niger, PN: Penicillum notatum, RS: Rhizopus stolonifer, -ve: Negative control (Hexane), +ve: Positive control; Gentamicin $10 \mu \mathrm{g} / \mathrm{mL}$ (bacterial) and Tioconazole $0.7 \mathrm{mg} / \mathrm{mL}$ (fungi).

\section{Conclusion}

Fifteen compounds were identified in the essential oil from the leaves of T. monadelpha wherein $\beta$-Caryophyllene was the most abundant compound. The predominance of the bioactive $\beta$-Caryophyllene which is known for its 
diverse pharmacological properties: antioxidant, wound healing, analgesic, anti-inflammatory, anti-anaphylactic, antidepressant and antimicrobial, in the leaf essential oil could be responsible for the diverse medicinal application of the plant in folk medicine. The results obtained justifies the uses of Trichilia monadelpha in folk medicine.

\section{Acknowledgements}

The authors are indebted to Chemistry Department, University of Ibadan where the research was carried out.

\section{Conflict of interest}

The authors declare that there is no conflict of interest.

\section{References}

Abbiw, D. K. (1990). Useful Plants of Ghana. Kew: Intermediate Tecgnology Publications and the Royal Botanic Gardens

Adams, R. P. (2001). Identification of Essential Oils by Trap Mass Spectroscopy. Allured Publishing Corporation, Carol Stream, IL

Bako, S. P., Bakfur, M. J., John, L.\& Bala, E.L. (2005). Ethnomedicinal and phytochemical profile of some savanna plant species in Nigeria. Int. J Bot., 1(2): 147-150.

Ben, I., Woode, E., Abotsi W., \& Boakye-Gyasi, E. (2013). Preliminary Phytochemical Screening and In vitro Antioxidant Properties of Trichilia monadelpha (Thonn.) JJ de Wilde (Meliaceae). Jour Med Biomed Sci., 2(2), 6-15

Benoit-Vical, F., Grellier, P., Abdoulaye, A., Moussa, I., Ousmane, A. \&Berry, A. (2006). In vitro and in vivo antiplasmodial activity of Momordica balsamina alone or in a Traditional Mixture. Chemotherapy, 52, 288-292

Bray, T. M. (1999). Antioxidants and oxidative stress in health and diseases: Introduction. Proc. Soc. Exp. Biol, Med., 222, 195-195

British Pharmacoepia. (1980). H. M. Stationary office, London. 2, 109

Burkill, H. M. (1997). The useful plants of West Tropical Africa, $2^{\text {nd }}$ Ed. Royal Botanic Gardens, Kew, London, United Kingdom. 4, 125-127

Cai, L. \& Wu, C. D. (1996). Compounds from Syzygium aromaticum possessing growth inhibitory activity against oral pathogens. J. Natural Products, 59, 987-90.

Dos Santos, D. A., Fukui, M. J., Dhammika, N. N.P., Khan, S.I., Sousa, J.P., Bastos, J.K., et al. (2010). Antiinflammatory and antinociceptive effects of Baccharis dracunculifolia DC (Asteraceae) in different experimental models. J Ethnopharmacol., 127,543-50

Fidyt, K., Fiedorowicz, A., Strza, L. \& Szumny, A. (2016). $\beta$-caryophyllene- and - $\beta$-caryophyllene-oxide natural compounds of anticancer and analgesic properties. Cancer Medicine, 5(10), 3007-3017. doi: 10.1002/cam4.816

Joulain, D. \& W.A Konig. (1998). The atlas of Spectral Data of Sesquiterpenes Hydrocarbons. E.B-Verlag Hamburg, Germany

Kalemba, D.\& Kunicka, A. (2003). Antibacterial and antifungal properties of essential oils. Curr. Med. Chem. 10 813-829 
Klauke, A.-L., Racz, I., Pradier, B., Markert, A., Zimmer, A. \& Gertsch, J. (2014). The cannabinoid CB 2 receptorselective phytocannabinoid beta- caryophyllene exerts analgesic effects in mouse models of inflammatory and neuropathic pain. Eur. Neuropsychopharmacol., 24,608-620. Doi: 10.1016/ j.euroneuro.2013.10.008 Kokate,

C.K. (2014). A Textbookfor Practical Pharmacognosy. 5th Ed.,Vallabh Prakashan Publishers, Delhi KwamiEdem,

K., Jeffrey, K., Mensah, A., Amoateng, P., Kwabena, S., Amponsah, B. N'G \& Asiedu-Gyekye. I. J. (2018). Antidepressant Potentials of Components from Trichilia monadelpha (Thonn.) J.J. de Wilde in Murine Model. Evidence-Based Complementary and Alternative Medicine. Volume Article ID 6863973, 11 pages https://doi.org/10.1155/2018/6863973

Langhasova, L., V. Hanusova, J., Rezek, B., Stohanslova, M., Ambroz, V., Kralova, et al. (2014). Essential oil from Myrica rubra leaves inhibits cancer cell proliferation and induces apoptosis in several human intestinal lines. Ind. Crops Prod., 59,20-26. doi:10.1016/ j.indcrop.2014.04.018

Langseth, L. (1996). Oxidants, antioxidants and disease prevention. International life Science Institute, Belgium

Mclafferty, F.W. \& Stauffer, D.B. (1989).The Willey/NBS Registry of Mass Spectral Data. John Wiley and Sons, New York

Medeiros, R., Passos, G. F., Vitor, C. E., Koepp, J., Mazzuco, L. T. L.\& Pianowski, F. (2007). Effect of two active compounds obtained from the essential oil of Cordia verbenacea on the acute inflammatory responses elicited by LPS in the rat paw. Br. J. Pharmacol., 151,618-627. doi:10.1038/sj.bjp.0707270

Odeja, O. O., Ibok, M. G., Okpala, E. O. \& Akpaeva, U. (2020). Chemical Composition, Antimicrobial and Antioxidant Activities of Root Essential Oil of Nigerian Specie of Asparagus Flagellaris (Kunth) Baker. International Journal of Innovative Research \& Development DOI No. : 10.24940/ijird/2020/v9/i5/152293375666-1-SM

Okpala, E. O, Oloyede, G.K. and Onocha, P. A. (2019). Chemical Composition, Antimicrobial and Antioxidant Activities of Volatile oil of Euphorbia graminea JACQ from Nigeria. International Journal of Advances in Science,Engineering and Technology, 7(4), 50-54

Oloyede, G. K., Odeja, O. O., Bamkole, O. A., Akanmu, W. A. \& Onocha, P. A. (2020). Hispanamide: an antioxidant phenolic propanamide from the leaves of Acalypha hispida (burn.f). Journal of Natural Sciences Research, $\quad 11(14), 11-16$

Oloyede, G. K., Onocha, P. A. \& Abimbade, S. F. (2011). Chemical Composition, Toxicity, Antimicrobial and Antioxidant activity of Leaf and Stem Essential Oils of Dieffenbachia picta (Araceae). European Journal of Scientific Research, 49(4), 567-580

Onocha, P. A., Oloyede, G. K. \& Akintola, J. A. (2016). Chemical Composition, free radical scavenging and antimicrobial activities of essential oil of Mariscus alternifolius Vahl. Open Conference Proceedings Journal, $7,160-167$

Onocha, P. A., Oloyede, G. K. \& Bamkole, O. A. (2011). UV-Visible investigation of Antioxidant and Toxicity activities of Methanolic fractions of Acalypha hispida (Burn.f) Leaves. European Journal of Scientific Research, $49(3), 322$

Potterat, O. (1997). Antioxidants and free Radical Scavenging of Natural Origin. Current Organic Chemistry, $1,415-\quad 440$ 
Quartey, A. K. (2014). Phytochemical, antimicrobial, and antioxidant constituents of the stem barks of Trichilia monadelpha (thronn) J.J. De Wilde and Trichilia tessmannii (harms) both of the family Meliaceae. A thesis submitted in fulfillment of the requirement for the degree of master of philosophy In Pharmaceutical Chemistry to the Department of Pharmaceutical Chemistry, Faculty of Pharmacy and Pharmaceutical Sciences, College of Health Sciences, Kwame Nkrumah University of Science And Technology, Kumasi. $\quad 90 p$.

Raskin, I., Ribnicky, D. M., Komarnytsky, S., Ilic, N., Poulev, A., Borisjuk, N., Brinker, A., Moreno, D. A., Ripoll, C. \& Yakoby, N. (2002). Plants and human health in the twenty-first century, Trends in Biotechnology 20, 522531

Sabulal, B., Dan, M., Kurup, R., Pradeep, N. S., Valsamma, R. K.\& George, V. (2006). Caryophyllene- rich rhizome oil of Zingiber nimmonii from South India: chemical characterization and antimicrobial activity. Phytochemistry 67, 2469-2473. doi:10.1016/ j.phytochem.2006.08.003.

Sato, M., Tsuchiya, H., Takase, I., Kureshiro, H., Tanigaki, S.\& Iinuma, M. (1995). Antibacterial activity of flavanone isolated fromSophora exigua against methicillin resistant Staphylococcus aureus and its combination with antibiotics. Phytotherapy Research, 9, 509-512

Senatore, F., Rigano, D., Formisano, C., Grassia, A., Basile, A. \& Sorbo. S. (2007). Phytogrowth inhibitory and antibacterial activity of Verbascum sinuatum. Fitoterapia, 78, 244-247

Singh, G., Marimuthu, P., C. S. de Heluani, and C. A. Catalan. (2006). Antioxidant and biocidal activities of Carum nigrum (seed) essential oil, oleoresin, and their selected components. J. Agric. Food Chem., 54,174-181. doi:10.1021/jf0518610.

Tiwari, P., Kumar, B., Kaur, M., Kaur, G. \&Kaur, H. (2011). Phytochemical screening and extraction: A review. Internationale Pharmaceutica Sci-encia, 1(1), 98-106

Woode, E., Abotsi W. \& Boakye-Gyasi, E. (2013). Preliminary Phytochemical Screening and In vitro Antioxidant Properties of Trichilia monadelpha(Thonn.) JJ de Wilde (Meliaceae). Jour Med Biomed Sci., 2(2), 6-15

Woode, E., Amoh-Barimah, A. K., Abotsi, W. K. M., Ainooson, G. K. \& Owusu, G. (2012). Analgesic effects of stem bark extracts of Trichilia monadelpha (Thonn.) JJ de Wilde, Indian Journal of Pharmacology, 44 (6), $765-\quad 773$ 